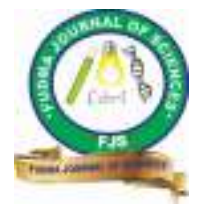

FUDMA Journal of Sciences (FJS)

ISSN online: $2616-1370$

ISSN print: 2645 - 2944

Vol. 4 No. 3, September, 2020, pp $52-59$

DOI: https://doi.org/10.33003/fjs-2020-0403-251

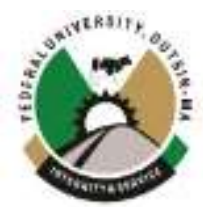

\title{
GROWTH PERFORMANCE AND SERUM BIOCHEMICAL PROFILE IN YANKASA RAMS FED ALKALI- TREATED GROUNDNUT SHELLS
}

\author{
${ }^{* 1}$ Millam, J. J., ${ }^{2}$ Bello, S. S., ${ }^{1}$ Abbaya, H. Y. and ${ }^{2}$ John, P. A. \\ ${ }^{1}$ Department of Animal Production, Adamawa State University, Mubi, Adamawa, Nigeria \\ ${ }^{2}$ Department of Animal Science, Ahmadu Bello University, Zaria, Kaduna Nigeria \\ *Corresponding Authors’ email: jacobjafiya@gmail.com; +2348061504098
}

\begin{abstract}
The study was conducted to assess the chemical composition of alkali treated groundnut shells and their effects on growth and serum biochemical parameters in Yankasa rams. A total of 4 Yankasa rams where used to conduct the experiment in a $4 \times 4$ Latin square design. Four diets ( $14 \%$ crude protein) were formulated to contain untreated groundnut shell (UTGNS), urea treated groundnut shell (UGNS), lime treated groundnut shell (LGNS) and urea-lime treated groundnut shell (ULGNS). Growth and blood serum parameters were measured at the end of each period. Samples of the treated groundnut shell and the experimental diets were analysed for proximate analysis, neutral detergent fibre, acid detergent fibre and lignin. The results of the chemical composition of treated groundnut shell showed that alkali chemical increased the protein, energy, and reduced the cell wall constituents of the untreated groundnut shell. Significant $(\mathrm{P}<0.05)$ effect were observed for daily weight gain, daily feed intake and feed conversion ratio and serum biochemical profile. Daily feed intake and daily weight gain were higher in UTGNS (183.50 g and $1110.90 \mathrm{~g}$ respectively); UGNS had the least feed conversion ratio (5.98). Total protein and glucose levels were above normal range of serum biochemical values for sheep while blood urea and creatinine were within normal range of values. The study revealed that dietary inclusion of treated groundnut shell did not show any negative effect on the growth performance and kidney function but indicated some signs of ailment on the activities of the liver and pancreas.
\end{abstract}

Keywords: Urea, lime, groundnut shell, feed intake, weight gain, feed conversion ratio, serum indices, and Yankasa rams.

\section{INTRODUCTION}

Forages, pastures, crop residues and other agro-industrial byproducts are the feed resource largely available for sheep in their lifetime (Kibon and Ørskov, 1993; Millam, 2016). These feed resource are affected by seasonality, making the animals experience seasonal body weight fluctuations during both seasons (dry and wet) of the year (Dayo et al., 2009; Aruwayo et al., 2011; Millam, 2016) due to its poor quality and quantity. Also, availability of such feed resource, clean water, and efficient medical care constitutes some of the constraints to livestock production (Glatzle, 1992; Aruwayo et al., 2011) which attributes to the major setback to ruminant production in Nigeria (Otaru et al., 2011; Millam, 2016).

Protein supplements such as groundnut cake, cotton seed cake, brewers dried grains are the frequent protein sources available during this period of low yield and poor quality herbage. But the prices of such feed materials are expensive which consequently leads to the rise production cost of keeping livestock (Maigandi, 2001; Aruwayo et al., 2011; Abdel Hameed et al., 2013). Researchers have now directed efforts towards considering the use of non-conventional feed source in order to curb the problem of cost of production, quantity and quality of feed stuff for ruminants (Aruwayo et al., 2011; Millam, 2016). Therefore, the perception of using abundant feed materials which are readily available for ruminant livestock production has consequently intensified research into evaluation of more crop residues for use as livestock feeds in
Nigeria (Aregheore, 2000; Malau-Aduli et al., 2003).

One feed material considered is the groundnut shell. Groundnut shell is an important threshing by-product from the nut of the groundnut plant. It is an important cash crop (Alu et al., 2012) largely (1.3 million tonnes) produced in the northern part of Nigeria annually (Akimfemi, 2010). It is usually considered as waste when the nut is processed for consumption (Alu et al., 2012). While the groundnuts are being produced, processed and consumed, the shells are usually left behind which creates an increasing problem of elimination (Akimfemi, 2010) especially in areas (Sokoto, Zamfara, Kano, Bauchi, Adamawa, Kaduna, Benue, Borno, Nasarawa and Anambara States) where they are produced in large quantities (Hostville, 2013; Millam, 2016). Ruminants in such areas largely depend on such crop residues for maintenance and production. The poor quality of these feed resources results in low plane of nutrition with attendant low productivity of the animals (Doma et al., 1999; Otaru et al., 2011). Groundnut shell is abundantly available from the month of October to May, it can supply enough roughage for ruminants in the country if properly harnessed and processed (Millam, 2016).

For now, groundnut shell could be cheap. Bean a waste, the only cost would be those of gathering and transporting to the point of use. Exploiting it for ruminant production would lower the market price of animal products. This would enable the Nigerian masses to increase their intake of animal protein (Akinfemi, 2010; Adamafio et al., 2012). Though, it has been 
noted for its poor nutritional status $(60 \%$ fibre, low digestibility), it can be improved through alkali treatment for utilization by ruminants (Millam, 2016). The feeding value of low quality crop residues can be improved through chemical treatment and alkali chemical have proved to be better for upgrading fibrous feeds (Khan et al., 2006). Therefore, the present study intends to use urea and lime to treat groundnut shell to determine the performance and serum biochemical parameters in Yankasa rams.

\section{MATERIALS AND METHODS}

The study was conducted at the Livestock Teaching and Research Farm of Ahmadu Bello University, Zaria located between latitude $11^{\circ} 04^{\prime} \mathrm{N}$ and longitude $7^{\circ} 42^{\prime} \mathrm{E}$ on an altitude of $706 \mathrm{~m}$ above sea level (Wikipedia, 2020).

Four (4) yearling (known through dentition) Yankasa rams weighing $\pm 21 \mathrm{~kg}$ were purchased from livestock market in Giwa L.G.A. in Kaduna State. The rams were kept under close supervision for two weeks. Acaricide solution were sprayed on their body to protect against ectoparasites, de-wormed with Anthelmintic drugs (Albendazol) and oxytetracycline (a broadspectrum antibiotic) given through intramuscular administration. The rams were kept under restriction and fed with mixture of cowpea and sorghum husk before the beginning of the trial. The animals were weighed using hanging balance to get their initial live weight and subsequent weights.
The groundnut shells (GNS); SAMNUT 10 variety, used in this study was obtained from the Legume Research Programme of the Institute for Agricultural Research, ABU Samaru, Zaria. The shells were dried under a shade for 5 days and later pulverized using a hammer mill fitted with $1 \mathrm{~cm}$ screen then stored in bags until when required for treatment. The processed GNS were treated with urea at $5 \%$, lime at $5 \%$ and urea-lime at $2.5 \%$ each, [i.e. $5 \mathrm{~g}$ urea was liquefied in 1 litre of water to treat $1 \mathrm{~kg}$ of GNS; $5 \mathrm{~g}$ lime was liquefied in 1 litre of water to treat $1 \mathrm{~kg}$ of GNS; and combination of $2.5 \mathrm{~g}$ urea and $2.5 \mathrm{~g}$ lime was liquefied in 1 litre of water to treat $1 \mathrm{~kg}$ of GNS, respectively]. The mixture (urea, lime, and urea-lime solution) was uniformly sprayed on the pulverized GNS and mixed thoroughly using a shovel on concrete floor (Can et al., 2004). The treated GNS were stored in a sealed Perdue Improved Cowpea Storage (PICS) double polyethylene bags for a period of 21 days as described by Al-Masri and Guenther (1999). Thereafter, they were spread on polyethylene sheet to air dry awaiting the start-up of experiment.

Alkali treated groundnut shells, cotton seed cake, maize offal, salt and bone meal were the composite ingredients of the experimental feeds. Four experimental diets containing 14\% crude protein were compounded. Treatment UTGNS was the control diet, it has GNS without treatment. Treatments UGNS, LGNS and ULGNS were made up of urea treated, lime treated and urea-lime treated groundnut shell respectively. Table 1 presents the composition of the experimental diets.

Table 1: Gross composition of the experimental diets

\begin{tabular}{lcccc}
\hline Ingredients $(\mathrm{kg})$ & UTGNS & UGNS & LGNS & ULGNS \\
\hline Maize offal & 35.65 & 46.3 & 44.9 & 50.55 \\
Cotton seed cake & 22.35 & 11.70 & 13.10 & 7.45 \\
GNS & 40.00 & 40.00 & 40.00 & 40.00 \\
Bone meal & 1.50 & 1.50 & 1.50 & 1.50 \\
Salt & 0.50 & 0.50 & 0.50 & 0.50 \\
Total & 100 & 100 & 100 & 100 \\
\hline UGNS: untreated groundnut shell, UTGNS: urea treated groundnut shell, LTGNS: lime treated groundnut \\
shell, ULTGNS: urea-lime treated groundnut shell.
\end{tabular}

The rams were kept in separate pen measuring $1.5 \times 1.5 \mathrm{~m}$. The diets were offered to the 4 rams in $4 \times 4$ Latin square design for the determination of growth performance and serum biochemistry.

The feed were offered without restriction to the rams in the morning and evening for 60 days; 15 days for each period of 4 . The rams were fed on a particular diet for 15 days then they were exchanged to the other feed as shown in Table 2.

Table 2: Experimental layout

\begin{tabular}{ccccc}
\hline Period & Ram 1 & Ram 2 & Ram 3 & Ram 4 \\
\hline 1 & T1 & T2 & T3 & T4 \\
2 & T2 & T3 & T4 & T1 \\
3 & T3 & T4 & T1 & T2 \\
4 & T4 & T1 & T2 & T3 \\
\hline
\end{tabular}

The cleaning and decontamination of the experimental pens was done a week before the start of the trial. The individual pen was equipped with water and feeding troughs that's allows unrestricted feeding and drinking with minimum wastage. Each morning, the feeding and water troughs were emptied and cleaned, then the next feed and water was offered. Each ram was weighed at the end of each period between $8.00 \mathrm{am}$ and 9.00 am during the course of the trial. The feed offered and left over were weighed and recorded before the next feeding in the morning. Feed intake were computed and recorded daily.
The jugular vein was severed and blood samples was collected in a $5 \mathrm{ml}$ syringe from each ram at the end of each experimental period (Coles, 1986). Bleeding was carried out at the early hours of the morning. An average of about $5 \mathrm{ml}$ of blood was collected from each ram. About $3 \mathrm{ml}$ of the blood collected was placed in a plane bottle and used for the analysis of total protein, blood urea and creatinine test. While the other $2 \mathrm{ml}$ was placed in a fluoride oxalate bottle and rotated horizontally to mix up with the chemical within it. The anticoagulated blood was used for glucose determination. 
Nessler's reaction was used to estimate the blood urea concentration (Tannins and Maylor, 1968). The Biuret method as described by Henry and Stobel (1957) was used to assess the total protein. Creatinine was ascertained by Jaffe reaction (Sarre and Nierenkrankheifen, 1959). Determination of the blood glucose levels was done by the Glucose Oxidase Principle (Beach and Turner, 1975).

Representative samples of the four experimental feeds, and treated groundnut shell samples were evaluated for proximate components as outlined by AOAC (2005). The cell wall constituent of the experimental diets and treated groundnut shells were revealed using the methods of Georing and Van Soest (1970).

Statistical Analysis: The data generated were analysed using the Generalised Linear Models Procedure (PROC GLM) of Statistical Analysis System package (SAS, 2002) in a one-way ANOVA. The treatment effect was tried and significant changes amongst treatment means was established by Duncan's Multiple Range Test (Duncan, 1955).

\section{RESULTS AND DISCUSSION}

Chemical Composition of Treated Groundnut shells and Experimental Diets

The chemical composition of the untreated and treated groundnut shell (GNS) used in the study are shown in Table 3. The values obtained indicates that both the treated and untreated GNS had high dry matter (DM) content $\pm 91.64 \%$. Untreated groundnut shell (UTGNS) had higher EE (ether extracts), lignin, ADF (acid detergent fibre), NDF (neutral detergent fibre) and values of $23.50 \%, 59.90 \%, 69.20 \%$, $64.00 \%$ and $2.00 \%$, respectively with lower CP (crude protein) level $(6.90 \%)$ compared to the treated GNS. Among the treated GNS, ULGNS had the highest CP value (15.43\%) while LGNS had the highest NFE (nitrogen free extracts) and Ash levels of $53.62 \%$ and $8.44 \%, \quad$ respectively.

Table 3: Chemical composition of urea and lime treated groundnut shells

\begin{tabular}{lcccc}
\hline Parameters (\%) & UTGNS & UGNS & LGNS & ULGNS \\
\hline Dry matter & 91.00 & 91.97 & 91.15 & 92.44 \\
Crude protein & 6.90 & 12.06 & 11.38 & 15.43 \\
Ether extract & 2.00 & 0.98 & 0.69 & 0.87 \\
Ash & 5.30 & 8.36 & 8.44 & 7.29 \\
Nitrogen free extract & 21.80 & 51.45 & 53.62 & 50.27 \\
Lignin & 23.50 & 14.12 & 12.08 & 11.11 \\
Acid detergent fibre & 59.90 & 29.36 & 31.88 & 29.87 \\
Neutral detergent fibre & 69.20 & 61.32 & 62.15 & 60.60 \\
\hline UTGNS: untreated groundnut shell, UGNS: urea treated groundnut shell, LGNS: lime treated groundnut \\
shell, ULGNS: urea-lime treated groundnut shell
\end{tabular}

The treatment of groundnut shell with urea, lime and urea-lime had slightly affected the NDF composition but increased the NFE, CP, ADF, lignin and ash. It was also observed that, treatment of GNS with alkali (UGNS, LGNS, and ULGNS) resulted in the cell wall constituents. It may be inferred that alkali treatment was effective in the hydrolysis of the fibrous structure of GNS to release available nutrients capsuled within the cell. As reported by Chaudhry (2000); Smith (2002) and Adamafio et al. (2012), when maize stalks and wheat straw was immersed in alkali, its degradation of the cellulose fraction was exceedingly effective.

Table 4: Chemical composition of the groundnut shells based diets

\begin{tabular}{lcccc}
\hline Parameters (\%) & UTGNS & UGNS & LGNS & ULGNS \\
\hline Dry matter & 92.17 & 94.04 & 91.88 & 94.13 \\
Crude protein & 16.69 & 17.94 & 18.25 & 17.56 \\
Ether extract & 4.18 & 4.56 & 4.19 & 4.78 \\
Ash & 4.52 & 4.87 & 6.19 & 5.10 \\
Nitrogen free extract & 66.20 & 65.24 & 66.45 & 67.90 \\
Lignin & 8.78 & 8.88 & 10.08 & 9.32 \\
Acid detergent fibre & 27.19 & 29.82 & 29.44 & 30.08 \\
Neutral detergent fibre & 54.28 & 50.88 & 49.87 & 52.22 \\
\hline UTGNS: untreated groundnut shell, UGNS: urea treated groundnut shell, LGNS: lime treated groundnut \\
shell, ULGNS: urea-lime treated groundnut shell
\end{tabular}

Cotton seed cake was believed to have boosted the level of protein $(\mathrm{CP})$ in all the diets, which gives them an amount which was greater than that $(15 \%)$ recommended by NRC (2007), for optimal production or upkeep for sheep. The high value of NDF with lower CP, EE, Ash and NFE in UTGNS could be as a result of the lignified nature of GNS in the diet because it was not treated with alkali. The improved CP levels, lower CF values and high NFE levels in the treated groups could be as a result of effective supplementation to the
Table 4 presents the outcome of the chemical constituents contained in the diets compounded for the trial. From the table, it can be observed that there was an increased the levels of DM (94.13\%), lignin (10.08\%), CP (18.25\%) and Ash $(6.19 \%)$ in LGNS; ADF (30.08\%), EE (4.78\%) and NFE $(67.9 \%)$ in ULGNS; and NDF (54.28\%) and CF (64.00\%) in UTGNS. However, UTGNS had the least lignin (8.78\%), ADF (27.19\%), CP (16.69\%), EE (4.18\%), Ash (4.52\%) and NFE (66.2\%). NDF contents was least in LGNS (49.87\%) while ULGNS had the lowest $\mathrm{CF}$ value of $4.66 \%$ when matched with the other treatment rations. 
groundnut shell (Smith, 1989).

\section{Growth Performance for Yankasa Rams Fed Experimental Diets}

The outcomes of the growth performance of the rams fed the experimental feeds are shown in Table 5 . The values points out that there was significant difference $(\mathrm{P}<0.05)$ in all parameters measured except initial weight which turn up to be nonsignificant $(\mathrm{P}>0.05)$. The findings observed from the table indicates that daily weight gain was higher significantly $(\mathrm{P}<0.05)$ in both UTGNS and LGNS $(183.50 \mathrm{~g}$ and $175.00 \mathrm{~g}$ respectively) compared to other treatments. The findings under this investigation also revealed highly significant difference in both daily feed intake and water intake for rams receiving UTGNS (1110.90 $\mathrm{g}$ and 3019.501 respectively) diets compared to the other treatments. Feed conversion ratio was least significantly $(\mathrm{P}<0.05)$ in both UGNS (5.98) and LGNS (7.15) compared to other treatments.

Table 5: Growth performance for Yankasa rams fed experimental diets

\begin{tabular}{|c|c|c|c|c|c|}
\hline Parameters & UTGNS & UGNS & LGNS & UTGNS & SEM \\
\hline Initial weight (kg) & 21.13 & 20.50 & 20.50 & 21.38 & 0.92 \\
\hline Final weight (kg) & $23.88^{\mathrm{a}}$ & $21.88^{\mathrm{b}}$ & $23.13^{\mathrm{ab}}$ & $22.75^{\mathrm{ab}}$ & 0.94 \\
\hline Weight gain $(\mathrm{kg})$ & $2.75^{\mathrm{a}}$ & $1.38^{\mathrm{b}}$ & $2.63^{\mathrm{a}}$ & $1.38^{\mathrm{b}}$ & 0.34 \\
\hline Daily weight gain $(\mathrm{g})$ & $183.50^{\mathrm{a}}$ & $91.75^{\mathrm{b}}$ & $175.00^{\mathrm{a}}$ & $91.75^{b}$ & 22.53 \\
\hline Daily feed intake $(\mathrm{g})$ & $1110.90^{\mathrm{a}}$ & $914.30^{\mathrm{b}}$ & $975.50^{\mathrm{b}}$ & $1088.10^{\mathrm{ab}}$ & 63.91 \\
\hline Water intake (l) & $3,019.50^{\mathrm{a}}$ & $2,562.00^{\mathrm{b}}$ & $2,693.80^{\mathrm{ab}}$ & $2,816.00^{\mathrm{ab}}$ & 176.75 \\
\hline Feed conversion ratio & $7.20^{\mathrm{ab}}$ & $5.98^{\mathrm{a}}$ & $7.15^{\mathrm{a}}$ & $10.06^{\mathrm{b}}$ & 1.44 \\
\hline
\end{tabular}

ab: Means with different superscripts within a row are significantly different $(\mathrm{P}<0.05)$, UTGNS: untreated groundnut shell, UGNS: urea treated groundnut shell, LGNS: lime treated groundnut shell, ULGNS: urea-lime treated groundnut shell, SEM: standard error of means

Higher weight gain detected in this study was in accordance with the works of Kade (2020) who fed treated groundnut shell to ram-lambs and reported a highest daily weight gain in the group of animals fed lime treatment. Although, lower values were reported by same author to be in the untreated group. The higher weight gain recorded in this study may be an indication of better nutrient utilization from the groundnut shells. This suggest that in order to achieve greater live weight gains in growing rams, the level of supplementation made to the group of animals receiving UTGNS and LGNS diets is adequate (Ansah et al., 2017; Khan et al., 2017). It may also be as a result that the rams fed UTGNS and LGNS had a better nutrient absorption and utilization which resulted in a significantly higher weight gain and daily weight gain as compared to those fed UGNS or ULGNS (McDonald et al., 2010).

Higher feed intake observed in this study with UTGNS was in conflict with the reports described by some authors (Gunun et al., 2013a, 2013b; Wanapat et al., 2013), who found out that the DM (dry matter) of treated rice straw improved the intake of dairy cows related to untreated rice straw. The authors also reported that urea-lime treatment could have the highest results among all treatments which was in conflict with the present study. The high feed intake in the animals receiving UTGNS diets of this study also conflicts the findings of Abdel Hameed et al. (2013) and Kade (2020) who reported that lambs fed treated GNS compared to the untreated GNS had increased feed intake. This could mean that raw GNS could have more effectiveness on intake of GNS in ruminants. This may also be as a result of the increased palatability of the diet due to supplementation with high fermentable carbohydrates and protein which improved the nutritive value of the feed (Smith, 1989; Melaku et al., 2004). The increase might also be as a result of high water intake which in turn aids in more saliva production that buffer the rumen $\mathrm{pH}$, softening the fibre, effective microbial activity in the rumen and enhanced fermentation. On the other hand, treatment with urea alone had a negative outcome on intake in the present study recording the lowest intake. This is in contrast to some researchers
(Sarnklong et al., 2010; Abdel Hameed et al., 2013; Wanapat et al., 2013) who demonstrated that treatment with urea will improve intake. However, Yulistiani et al. (2015) reported that urea treated rice straw did not increase intake when fed to sheep. This finding is similar to the results obtained in this study. Lower intake in the group of rams receiving UGNS diet recorded in this study might be attributed to animal differences of feed acceptability (Huyen et al., 2012). Furthermore, the limitation for the intake might be as a result of slow digestion (Distel et al., 1994) or distension of the rumen wall (Grovum, 1988).

The least feed conversion ratio observed in the set of rams receiving UGNS and LGNS observed under this investigation is comparable with the works of Kade (2020) who fed treated groundnut shell to ram-lambs and observed least FCR in the group of animals receiving lime treated diets (8.94). The efficacy of feed use for growth is affected by energy loss as heat, or heat augmentation (McDonald et al., 2010). The higher the heat loss, the less the feed utilization, thus reduced growth and vice versa. This means that, when the poor quality status of feed materials for ruminants are improved (either through treatment or supplementation or any other means) to reduce lignin concentration, efficient feed utilization will improve growth. This may be the situation as observed in the group of animals receiving experimental diets UGNS (Table 3). Likewise, the emanation of enteric methane was found to be affected by diet quality; increased lignin produces higher emission and vice versa (O'Hara et al., 2003). The growth of ruminants is influeneced positively when more gross energy is conserved as a result of lower methane emission (Ansah et al., 2017). In the present study, methane was not quantified, but may be a contributor to differences in utilization of nutrients. More so, lower concentration of non-photosynthetic tissues and lower lignin concentration may also account for improved growth performance in ruminants (Wilson and Kennedy, 1996; Ansah et al., 2017). 
Serum biochemical parameters in Yankasa rams fed experimental diets

Table 6 revealed the results of the serum biochemical parameters in Yankasa rams fed experimental diets. All serum biochemical indices measured revealed significant effect $(\mathrm{P}<0.05)$ when the experimental diets was fed to the Yankasa rams. Values for total protein was observed to higher significantly $(\mathrm{P}<0.05)$ in groups receiving UTGNS $(129.25$ $\mathrm{g} / \mathrm{L})$ experimental diets compared to other treatments. The group of animals receiving UGNS $(4.73 \mathrm{mmol} / \mathrm{L})$, LGNS $(4.88$ $\mathrm{mmol} / \mathrm{L})$ and ULGNS $(5.08 \mathrm{mmol} / \mathrm{L})$ experimental diets had values that were significantly higher for serum glucose. Values for blood urea nitrogen and creatinine were observed to be higher significantly in the group animals receiving UGNS $(5.00 \mathrm{mmol} / \mathrm{L}$ and $164.75 \mu \mathrm{mol} / \mathrm{L}$ respectively) experimental diets compared to other treatments.

Table 6: Serum biochemical parameters in Yankasa rams fed experimental diets

\begin{tabular}{|c|c|c|c|c|c|c|}
\hline Parameters & UTGNS & UGNS & LGNS & UTGNS & SEM & Normal range \\
\hline Total protein $(\mathrm{g} / \mathrm{L})$ & $129.25^{\mathrm{a}}$ & $93.00^{\mathrm{c}}$ & $119.75^{\mathrm{ab}}$ & $108.50^{\mathrm{b}}$ & 9.47 & $60-79$ \\
\hline Glucose $(\mathrm{mmol} / \mathrm{L})$ & $3.98^{\mathrm{b}}$ & $4.73^{\mathrm{a}}$ & $4.88^{\mathrm{a}}$ & $5.08^{\mathrm{a}}$ & 0.20 & $2.78-4.44$ \\
\hline Urea nitrogen $(\mathrm{mmol} / \mathrm{L})$ & $4.63^{\mathrm{b}}$ & $5.00^{\mathrm{a}}$ & $3.18^{\mathrm{c}}$ & $2.70^{\mathrm{d}}$ & 0.16 & $2.8-7.1$ \\
\hline Creatinine $(\mu \mathrm{mol} / \mathrm{L})$ & $150.25^{b}$ & $164.75^{\mathrm{a}}$ & $138.50^{\mathrm{b}}$ & $153.00^{\mathrm{ab}}$ & 6.14 & $106-168$ \\
\hline
\end{tabular}

abcd: Means with different superscripts within a row are significantly different $(\mathrm{P}<0.05)$, UTGNS: untreated groundnut shell, UGNS: urea treated groundnut shell, LGNS: lime treated groundnut shell, ULGNS: urea-lime treated groundnut shell, SEM: standard error of means

Blood parameters are important indices of physiological, pathological and nutritional status in living organisms (Ewuola et al., 2004). Serum biochemistry analysis is used to determine the level of heart attack, liver damage and to evaluate protein quality and amino acid requirements in animals as reported by Harper et al., (1979). The biochemical values for total protein did not kow-tow the values of Nayawo et al. (2017) and Aruwayo et al. (2011), the authors documented lower values of total protein after feeding Yankasa rams with urea treated rice straw. The increase in total protein could probably be due to increased protein content in the diet as well as increased protein intake. This may also imply that the diets supplied more than enough protein to maintain normal serum protein levels (Aruwayo et al., 2011). Values for the total protein obtained in this study are higher than those of the normal range $(60-79 \mathrm{~g} / \mathrm{L})$ recommended for sheep as reported by Kaneko et al. (2008) and Latimer (2011).

Concentration of serum glucose indicates the metabolism of carbohydrate in high energy feeds (Coles 1986). The serum glucose in the study had reduced levels, lower than the values reported by Nayawo et al. (2017), the authors observed higher level of blood glucose in Yankasa ram fed urea treated rice straw. The results of serum glucose observed in this study were above the values of normal ranges $(2.78-4.44 \mathrm{mmol} / \mathrm{L})$ recommended for sheep (Kaneko et al., 2008; Latimer, 2011). Serum glucose of the group of animals receiving UTGNS experimental diets which was within normal range. The increase above normal range may be attributed to increased intake in soluble carbohydrates (hyperglycaemia) leading to increased level of blood glucose (Wada et al., 2014). This is in support of Abd El Latif (2003) who indicated that values of blood glucose concentration in growing Friesian calves were correlated with the energy in the diets.

Blood urea is a product of protein metabolism which is usually found to be high in adult sheep than younger ones. Urea measurement is used especially to indicate renal disease and to a lesser extent liver dysfunction (Kaneko et al., 1997). The blood urea levels detected in the present trial were all within normal range $(2.8-7.1 \mathrm{mmol} / \mathrm{L})$ recommended for sheep (Kaneko et al., 2008; Latimer, 2011). This is an indication that there was no kidney dysfunction or the diets provided adequate protein for the animals (Aruwayo, et al., 2011). The higher values of blood urea nitrogen for rams receiving UGNS diets in this study might be as a result of high release of ammonia in the rumen resulting to high absorption of ammonia from the rumen into the blood (Abubakar et al., 2010; Gunun et al., 2013b; Nayawo et al., 2017). Also, Yadav and Yadav (1988) reported increased in blood urea in cattle fed treated straw compared to the untreated.

Creatinine testing is used to diagnosis impaired renal function or renal disease along with blood urea nitrogen (Sodano and Grisanti, 2010). The levels of creatinine recorded in this study were all within normal range $(106-168 \mu \mathrm{mol} / \mathrm{L})$ recommended for sheep (Kaneko et al., 2008; Latimer, 2011). This shows that the treatment of groundnut shell with alkali chemical did not compromise the renal function of the rams. The levels of creatinine in conjunction with blood urea concentrations point towards a normal kidney.

\section{CONCLUSION}

The result obtained in this study indicated that dietary inclusion of treated groundnut shell in the diet of Yankasa rams supplied nutrients needed by the rams, decreased intake of feed, increased gain of weight and feed conversion ratio. The blood biochemical parameters recorded in this trial were within levels recommended for blood urea and creatinine while that of total protein and glucose where above recommendation for sheep. This implies that the diets containing treated groundnut shell were not harmful for the kidney but had effects on the pancreas and liver. Therefore, it can be concluded that, inclusion of treated groundnut shell in the diets of Yankasa rams did not revealed any negative effect on the growth and kidney performance but showed some signs of ailment on the activities of the liver and pancreas. Urea treated groundnut shell may be used in diets of ruminants with minimum health complications.

\section{REFERENCE}

Abdel Hameed, A.A., Fedel Elseed, A.M., and Salih, A.M. (2013). Growth Performance and Rumen Fermentation of Lambs Fed Untreated or Urea Treated Groundnut Hull with Different Protein Sources. Journal of Animal Production 
Advances, 3(3): 86-96.

Abd El Latif, E.S.K. (2003). Nutrtiional studies on beef cattle. M. Sc Dissertation, Faculty of Agriculture, Cairo University, Cairo. pp: 119

Abubakar, M., Adegbola, T.A., Abubakar, M.M., Shehu, Y., Ngele, M.B. and Kalla, D.J.U. (2010). Nutritional evaluation of different sources of nitrogen on digestible nutrient intake, nitrogen balance and production of rumen metabolites in growing Yankasa sheep. Emirates Journal of Food and Agriculture, 22(4): 298-307.

Adamafio, N.A., Addo, P., Osei-Boadi, K., and Janha, R. (2012). Potash Pre-treatment Enhances Carbohydrate Biodegradability and Feed Potential of Groundnut (Arachis hypogia) Shell Meal.pdf. Journal of Applied Sciences, 12(6): 1408-1412.

Akinfemi, A. (2010). Bioconversion of peanut husk with white rot fungi: Pleurotus ostreatus and Pleurotus pulmonarius. Livestock Research for Rural Development, 22(3): 1-11.

Al-masri, M.R., and Guenther, K.D. (1999). Changes in digestibility and cell-wall constituents of some agricultural byproducts due to gamma irradiation and urea treatments. Radiation Physics and Chemistry, 55: 323-329.

Alu, S.E., Adua, M.M., Damulak, H.I., Umar, R.S., Abubakar, A.D., and Matthew, U.D. (2012). Growth rate and nutrient digestibility by broiler birds fed alkali-treated groundnut (Arachis hypogea) shell meal-based diets. Scholarly Journal of Agricultural Science, 2(10): 231-237.

Ansah, T., Yaccub, Z.I. and Rahman, A.N. (2017). Growth performance and haematology of Djallonke rams fed haulms of four varieties of groundnut (Arachis hypogaea L.). Animal Nutrition, 3(2017): 406-410.

AOAC, (Association Of Analytical Chemist). (2005). Official Method of Analysis (17th ed.). Maryland, USA: AOAC International.

Aregheore, E.M. (2000). Chemical composition and nutritive value of some tropical by-product feedstuffs for small ruminants - in vivo and in vitro digestibility. Animal Feed Science and Technology, 85(2): 99-109.

Aruwayo, A., Maigandi, S.A., Malami, B.S. and Daneji, A.I. (2007). Performance of lambs fed fore-stomach digesta and poultry litter waste. Nigerian Journal of Basic Applied Sciences, 15(1\&2): 86-93.

Beach, G.E., and Turner, T.D. (1975). Toxicology. Oxford England: Oxford University Press.

Can, A., Denek, N., Tufenk, S., and Bozkurt, A. (2004). Determining Effect of Lime and Urea Treatment on Crude and Digestible Nutrient Content of Wheat Straw. Journal of Animal and Veterinary Advances, 3(7): 479-482.
Chaudhry, A.S. (2000). Rumen degradation in sacco in sheep of wheat straw treated with calcium oxide, sodium hydroxide and sodium hydroxide plus hydrogen peroxide. Animal Feed Science and Technology, 83(1): 313-323.

Coles, E.H. (1986). Veterinary Clinical Pathology (4th Edition). W.B. Sunders Company, Harcourt Brace Jovanovidi, Inc.

Dayo, P., Ephraim, N., John, P. and Omobowale, A.O. (2009). Constraints to increasing agricultural productivity in Nigeria. Nigeria Strategy Support Programme (NSSP) Background Paper No. NSSP 06, International Food Policy Research Institute, Washington D.C., USA.

Distel, R.A., Villalba, J.J., and Laborde, H.E. (1994). Effects of early experience on voluntry intake of low-quality roughage by sheep. Journal of Animal Science, 72: 1191-1195.

Doma, U.D., Mohammed, L.K., and Umeh, A.P. (1999). Observation on the characteristics of small holder sheep and goat management practice in old Bauchi State. Tropical Journal of Animal Science, 2: 125-130.

Duncan, D.B. (1955). Multiple Ranges and Multiple F-Tests. Biometrics, 11: 14-20.

Ewuola, E.O., Folayan, O.A., Gbore, F.A., Adebunmi, A.I., Akanji, R.A., Ogunlade, J.T. (2004). Physiological response of growing West African Dwarf goats fed groundnut shell-based diets as the concentrate supplements. Bowen Journal of Agriculture, 11: 61-69.

Georing, H.K., and Van Soest, P.J. (1970). Forage Fibre Analysis (Apparatus, Reagents, Procedures and some Applications). Washington, DC: U.S. Agricultural Reserch Service.

Glatzle, A. (1992). Feed Resources in the Sahel. Animal Research and Development, 35: 43-58.

Grovum, W.L. (1988). Appetite, palatability and control of feed intake. In The Ruminant Animal, Ed., D. C. Church. Englewood Cliffs, NJ: Pretence-Hall. pp: 202-216

Gunun, P., Wanapat, M., and Anantasook, N. (2013a). Effects of Physical Form and Urea Treatment of Rice Straw on Rumen Fermentation, Microbial Protein Synthesis and Nutrient Digestibility in Dairy Steers. Asian-Australasian Journal of Animal Sciences, 26(12): 1689-1697.

Gunun, P., Wanapat, M., and Anantasook, N. (2013b). Rumen Fermentation and Performance of Lactating Dairy Cows Affected by Physical Forms and Urea Treatment of Rice Straw. Asian-Australasian Journal of Animal Sciences, 26(9): 12951303.

Harper. H., Rodwell, V.W. and Mayer, P.A. (1977). Review of Physiological Chemistry. (6th edn). California Lange Medical Publishers. Pp: 559-598. 
Henry, R.J. and Stobel, C. (1957). Determination of serum proteins by the burrette reaction. Analytical Chemistry, 92: 1491.

Hostville. (2013). Upgrading Crop Residues for Effective Utilization by Ruminant Livestock. Resourcedat. Retrieved April 24, 2020, from http://resourcedat.com/document/upgrading-crop-residues-foreffective-utilization-by-ruminant-livestock/

Huyen, N.T., Wanapat, M., and Navanukraw, C. (2012). Effect of mulberry leaf pellet (MUP) supplementation on rumen fermentation and nutrient digestibility of beef cattle fed on rice straw-based diets. Animal Feed Science Technology, 175: 8-15.

Kade, B.I.D. (2020). Groundnut shell used in sheep production: feeding treated groundnut to growing ram lambs and fattening Yankasa rams. Saarbrücken, Germany: LAP Lambert Academic Publishing. pp: 176

Kaneko, J.J., Harvey, J.W. and Bruss, M. (1997). Clinical Biochemistry of Domestic Animals. 5th ed. Elsevier/ Academic Press, Amsterdam. pp: 932.

Kaneko, J.J., Harvey, J.W. and Bruss, M.L. (2008). Clinical Biochemistry of Domestic Animals, 6th Ed. London, UK: Academic Press. pp: 928.

Khan, M.A., Sarwar, M., Nisa, M., Khan, M.S., Bhatti, S.A., Iqbal, Z., and Ki, K.S. (2006). Feeding Value of Urea Treated Wheat Straw Ensiled with or without Acidified Molasses in Nili-Ravi Buffaloes. Asian-Australasian Journal of Animal Sciences, 19(5): 645-650.

Khan, M.T., Khan, M.I., Raza, S.H.A., Adnan, M., Khan, R., Hosseini, S.M., Syed, S.F., Adrian shah, S.K., Khan, M.A. and Ahmad, A. (2017) Effect of Urea Treated Groundnut Shells on Feed Intake, Digestibility, Nitrogen Retention and Economic Value in Growing Rabbits. International Journal Poultry and Fisheries Science, 1(1): 1-7.

Kibon, A., and Ørskov, E.R. (1993). The Use of Degradation Characteristics of Browse Plants to Predict Intake and Digestibility by Goats. Journal of Animal Production, 57(2): 247-251.

Latimer, K.S. (2011). Duncan \& Prasse's Veterinary Laboratory Medicine: Clinical Pathology, 5th Ed. Iowa, USA: Wiley-Blackwell. Pp: 528.

Maigandi, S.A. (2001). Quantification and Utilization of Forestomach Digesta in the Diets of Growing and Fattening Sheep. $\mathrm{Ph}$ D. Thesis. Department of Animal Science, Faculty of Agriculture, Usmanu Danfodiyo University, Sokoto, Nigeria. pp: 129. (Unpublished).

Malau-Aduli, B.S., Eduvie, L., Lakpini, C.A.M., and MalauAduli, A.E.O. (2003). Chemical compositions, feed intakes and digestibilities of crop-residue based rations in non-lactating Red Sokoto goats in the sub-humid zone of Nigeria. Animal
Science Journal, 74(2): 84-94.

McDonald, P., Edwards, R.A., Greenhalgh, J.F.D., Morgan, C.A., Sinclair, L.A., and Wilkinson, R.G. (2010). Animal Nutrition. (C.A. Morgan, J.F.D. Greenhalgh, L.A. Sinclair, \& R.G. Wilkinson, Eds.) (Seventh.). Harlow, England: Prentice Hall. pp: 275

Melaku, S., Peters, K.J., and Tegegne, A. (2004). Intake, digestibility and passage rate in Menz sheep fed tef (Eragrostis tef) starw supplemented with dried leaves of selected multipurpose trees, thier mixtures or wheat bran. Small Ruminal Research, 56: 139-149.

Millam, J.J. (2016). Effects of urea and lime treated groundnut shell in mixed diets on nutrient intake and in situ degradation in Yankasa rams. M. Sc Dissertation, Depaertment of Animal Science, Ahmadu Bellow University, Zaria.

Nayawo, A.A., Ishaku, S., Mijinyawa, M.A., Ehoche, W.O., Otaru, S.M., and Abdu, S.B. (2017). Serum biochemical profiles of fattening Yankasa rams fed diets containing different proportions of urea treated rice straw and gamb hay. International Jouranl Agroculture and Earth Science, 3(7): 1823.

NRC, (National Research Council). (2007). Nutritional Requirements of Domestic Animals: Nutrient Requirments of Sheep. National Research Council (NRC, Ed.) (Seventh Re.). Washington DC, USA.: National Academies Press.

O'Hara, P., Freney, J. and Ulyatt, M. (2003). Abatement of agricultural non-carbon dioxide greenhouse gas emissions e a study of research requirements, a report prepared for the Ministry of Agriculture and Forestry, New Zealand.

Otaru, S.M., Adamu, A.M., Ehoche, O.W., and Makun, H.J. (2011). Effects of varying the level of palm oil on feed intake , milk yield and composition and postpartum weight changes of Red Sokoto goats. Small Ruminant Research, 96(1): 25-35.

Sarnklong, C., Cone, J.W., Pellikaan, W., and Hendriks, W.H. (2010). Utilization of Rice Straw and Different Treatments to Improve Its Feed Value for Ruminants: A Review. AsianAustralasian Journal of Animal Sciences, 23(5): 680-692.

Sarre, H. and Nierenkrankheifen, T. (1959). Jaffe reactions: Photometric colometric test for end point measurement. Biochemistry Zeitschr, 291: 354.

SAS, (Statistical Analysis Systems). (2002). Procedures Guide. North Carolina, USA: Statistical Analysis Systems Institute, Cary.

Smith, O.B. (1989). Utilization of crop residues in the nutrition of sheep and goats in the humid tropics of West Africa. In V. M. Timon \& R. P. Baber (Eds.), Proceedings of a seminar held in Yamoussoukro, Côte d'lvoire 21-25 September 1987. Yamoussoukro, Côte d'lvoire: Agriculture and Consumer Protection, FAO. pp: 1-16 
Smith, T. (2002). On-Farm Treatment of Straws and Stovers with Urea. In IAEA (Ed.), Proceedings of the final review meeting of an IAEA Technical Co-operation Regional AFRA Project organized by the Joint FAO/IAEA Division of Nuclear Techniques in Food and Agriculture and held in Cairo, Egypt, 25-29 November 2000. Vienna, Austria: International Atomic Energy Agency (IAEA). pp: 170

Sodano, W.L. and Grisanti, R. (2010).Functional Diagnostic Medicine Training Program Mod 1* Lesson 7: Blood Chemistry \& CBC Analysis. Functional Medicine University. pp: 13

Tannis, R.J. and Maylor, A.W. (1968). Physical and Chemical studies of low molecular weight form of cheese. Biochemistry Journal, 108: 771-775.

Wada, N.I., Njidda, A.A., Adamu, M. and Chibuogwu, C.I. (2014).Variation in haematological and serum biochemical indices of sheep fed Ziziphus mucronata and Parkia biglobosa (A comparative study). Global journal of Biology, Agriculture and Health science, 3(4): 39-47.

Wanapat, M., Kang, S., Hankla, N., and Phesatcha, K. (2013). Effect of rice straw treatment on feed intake, rumen fermentation and milk production in lactating dairy cows. African Journal of Agricultural Research, 8(17): 1677-1687.
Wikipedia. (2020). The Free Encyclopaedia. WIKIPEDIA. Ahmadu Bello University. Retrieved January 24, 2020, from http://en.wikipedia.org/wiki/Ahmadu_Bello_University

Wilson, J.R. and Kennedy, P.M. (1996). Plant and animal constraints to voluntary feed intake associated with fibre characteristics and particle breakdown and passage in ruminants. Australian Journal of Agricultural Research, 47: 199-225.

Yadav, B.P.S. and Yadav, I.S. (1988). Nitrogenous constituent in rumen metabolites and blood serum of adult cattle fed urea treated straws. Indian Journal of Animal Science, 58: 107.

Yulistiani, D., Jelan, Z.A., Liang, J.B., Yaakub, H., and Abdullah, N. (2015). Effects of Supplementation of Mulberry (Morus alba) Foliage and Urea-rice Bran as Fermentable Energy and Protein Sources in Sheep Fed Urea-treated Rice Straw Based Diet. Asian-Australasian Journal of Animal Sciences, 28(4): 494-501. 